\title{
A CRITICAL ANALYSIS OF THE PROPOSED CODIFICATION OF THE DUTIES OF CORPORATE DIRECTORS
}

\author{
By Rudolph Martin de Neijs*
}

\section{Introduction}

In pursuance of the rectification of perceived shortcomings in the common law duties of directors, including inter alia the confusion and uncertainty among prospective and current directors concerning the degree of skill expected of them while carrying out their functions, the Department of Trade and Industry prepared a discussion draft of a proposed new Companies Act for South Africa, ${ }^{1}$ which, in contrast with the previous Companies Act, ${ }^{2}$ spelled out the duties of corporate directors. Following the discussion draft, a new Companies Bill was introduced in June 2008 in the spirit of the February 2007 bill regarding directors' duties.

In this article I shall attempt to outline the new statutory duties and other relevant sections and explain these duties as they are found in the Companies Bill.

It should be stated that since the following discussion concerns proposed law not yet in force, no court decisions and very few academic articles are available to aid the interpretation thereof. The following interpretations are thus purely speculative and may differ from the ultimate interpretation that the court may give to these sections when applied. The interpretation of these sections can further not be aided by English statutory law, as the English statutory law only refers to fiduciary duties of directors and does not contain any specific criteria of care and skill by which a director's conduct can be measured. ${ }^{3}$

* $\quad$ Final year LLB student (University of Pretoria).

1 Draft Companies Bill for public comment, 31 October 2006 as published for public comment in February 2007. The Companies Bill was introduced in the National Assembly in June 2008.

2 Act 61 of 1973.

3 Campbell et al (eds) Liability for Corporate Directors (1993) 222-232. 


\section{The new Companies Bill}

\subsection{Duty of care and skill as proposed by the new Companies Bill}

Section 76 of the new Companies Bill contains both positive (care and skill) and negative (fiduciary) duties of directors. Of importance to this article are the positive duties contained therein. I will now provide and elaborate on the subsections which form the anticipated new duties.

\subsubsection{Section 76(3) of the Companies Bill}

Section $76(3)$ reads as follows:

3. Subject to subsections (4) and (5), a director of a company, when acting in that capacity, must exercise the powers and perform the functions of director-

(a) ...;

(b) $\ldots$; and

(c) with the degree of care, skill and diligence that may reasonably be expected of a person-

(i) carrying out the same functions in relation to the company as those carried out by that director; and(ii)having the general knowledge, skill and experience of that director.

From the above, the following can be distilled:

According to section 76(3)(c) there will be a two-stage test according to which a director's conduct will be measured, which consists of an objective and a subjective leg. Section 76(3)(c)(i) sets out an objective test by which the director's care and skill applied during his conduct is compared to the general knowledge, skill and experience that may reasonably be expected of an individual carrying out the same functions as are carried out by that particular director. A director thus takes a large risk when accepting an appointment to a position where specialised knowledge is required, as he will be judged according to the standard of such an expert. Therefore, it may be said that section $76(3)(c)(i)$ introduced the maxim imperitia culpae adnumeratur - literally translated to mean that ignorance or lack of skill is deemed to be negligence - into the field of directors' duties. ${ }^{4}$ It follows that section 76(3)(c)(i) lays out the minimum standard by which a director's conduct is measured.

Section 76(3)(c)(ii) contains the subjective leg of the test. According to this section, should a director have certain special knowledge, expertise or experience over and above the minimum 
which may reasonably be expected from someone holding his office, he will be judged according to a higher standard, that is according to the care, skill and diligence someone with his special knowledge should have applied in carrying out his particular obligation. This section thus focuses on the subjective personal knowledge of a director and can only increase the standard by which a director's conduct will be tested over and above the objective standard described in 76(3)(c)(i).

\subsubsection{Section 76(4)(a) of the Companies Bill}

Section 76(4)(a) reads as follows:

(4) In respect of any particular matter arising in the exercise of the powers or the performance of the functions of director, a particular director of a company-

(a) will have satisfied the obligations of subsection (3)(b) and (c) if-

(i) the director has taken reasonably diligent steps to become informed about the matter;

(ii) ...;

(aa) ...;

(ab) ...; and

(iii) the director made a decision, or supported the decision of a committee or the board, with regard to that matter, and the director had a rational basis for believing, and did believe, that the decision was in the best interests of the company; and ...

From the above the following can be distilled:

Section 76(4)(a)(i) states that a director will have acted reasonably if he has taken reasonably diligent steps to become informed about the subject matter of a specific judgment and can as a result not use ignorance as an excuse for poor judgment or performance.

The relevance of section 76(4) lies in the following: A director will be in breach of his duties if he conducted his obligations without the necessary degree of skill, that is if he conducted himself negligently. With the Aquilian action, it becomes a difficult issue to determine whether or not a director has fault in the form of negligence with regard to a certain obligation that he performed as it is not always clear what should reasonably be expected from a director and because courts are loath to second-guess directors' decisions. Section 76(4) gives clarity on when a director's actions will have fallen short of being reasonable and will thus have been negligent.

This section creates the impression that there is no distinction between the criteria which will be applied when determining whether executive directors or non-executive directors have acted negligently, as both are expected to become properly informed before making a decision. This assumption is strengthened by section 76(1) which states that section 76 will also apply to an alternate 
director, which is a form of temporary ad hoc director. ${ }^{5}$ It is submitted that as this section applies equally to alternate directors who are not permanently occupied with the business of the company, it will also equally apply to non-executive directors.

\subsubsection{Sections 76(4)(b) and 76(5) of the Companies Bill}

Sections 76(4)(b) and 76(5) read as follows:

(4) A director

(b) is entitled to rely on-

(i) the performance by any of the persons-

(aa) referred to in subsection (5); or

(ab)to whom the board may reasonably have delegated, formally or informally by course of conduct, the authority or duty to perform one or more of the board's functions that are delegable under applicable law; and

(ii) any information, opinions, recommendations, reports or statements, including financial statements and other financial data, prepared or presented by any of the persons specified in subsection (5).

(4) To the extent contemplated in subsection (4)(b), a director is entitled to rely on-

(b) one or more employees of the company whom the director reasonably believes to be reliable and competent in the functions performed or the information, opinions, reports or statements provided; (c) legal counsel, accountants, or other professional persons retained by the company, the board or a committee as to matters involving skills or expertise that the director reasonably believes are matters-

(i) within the particular person's professional or expert competence; or

(ii) as to which the particular person merits confidence; or

(d) a committee of the board of which the director is not a member, unless the director has reason to believe that the actions of the committee do not merit confidence.

From the above, the following can be distilled:

A director is entitled to trust that a delegate will perform his function properly or that the information supplied by such delegate is accurate, subject to certain requirements. These requirements can be elaborated on as follows:

A director can rely on any person to perform any of the board's functions properly provided the specific authority is legally capable of delegation and the board could reasonably delegate such authority to the person in question. It is submitted that section 76(4)(b)(i)(bb), in contrast with section 76(5), does not expressly put any duty on the director to be convinced of the competency or trustworthiness of the delegate. 
A director may also rely on the performance or information given by employees or professional persons retained by the company provided the director reasonably believes the specific authority, duty or information falls within the specific delegate's competence and that the delegate is reliable.

Section 76(5)(b) gives criteria by which a director can judge if a professional person is competent with regard to the specific authority or duty. Section 76(5)(b)(i) appears to indicate that a director may rely on a professional person to perform a function or give accurate information if the particular function or information falls within the qualifications of the person. It is submitted that, according to this section, a director may trust that a professional person is competent in the area of his qualifications, provided he has no reason to doubt that person's competence, because it would be reasonable to believe someone with specialised qualifications is proficient in such subject matter.

Section 76(5)(b)(ii) appears to indicate that a director may also rely on the performance or information of a professional person regarding matters that the director reasonably believes fall within that particular person's competence. It is submitted that this section allows a director to entrust a professional person with authority which falls outside their qualifications, but in which the director has reason to believe the particular person is competent.

Furthermore, a director is allowed to rely on the performance or information of a committee of the board, even though the director is not a member. As with all persons mentioned in this section, this is subject to the director's reasonable belief that such persons are trustworthy and competent.

\section{Basis of liability for breach of director's duties}

\subsection{Section 77(2) of the Companies Bill}

Section $77(2)$ reads as follows:

(2) A director of a company may be held liable-

(a) ...; or

(b) in accordance with the principles of the common law relating to delict for any loss, damages or costs sustained by the company as a consequence of any breach by the director of-

(i) a duty contemplated in section $76(3)$ (c);

(ii) any provision of this Act not otherwise mentioned in this section; or (iii) ...;

This section makes provision for the enforcement of a director's duty of care and skill by making the common law of delict the basis for liability for any breach. Section 77(2)(b)(i) applies directly to a 
director's duty of care and skill, while section 77(2)(b)(ii) will have application on the ancillary duties, such as that described in section 76(5).

\section{Conclusion}

In this article I have argued that the new Companies Bill contains sections which attempt to codify the duty of care and skill expected from a director. I have shown that the codified duties in the Companies Bill can roughly be divided into two categories: the care and skill a director must apply when conducting the company's business, and when a director may rely on another to perform the duties expected from him. I have also attempted to give guidelines for the interpretation of these duties.

The Bill makes no mention of whether the new director's duties are supplementary to the common law duties or override them. It is furthermore difficult to draw a conclusion purely from such an omission, as the Bill specifies in other sections when it abolishes the common law and when it is merely supplementary. ${ }^{6}$ However, it is submitted that as the February 2007 draft contained a clause stating that the new duties operate concurrently with the common law duties, the omission was intentional and thus the new duties abolish and replace the common law duties. 